Original Research Paper

\title{
Pendugaan Ukuran Pertama Kali Matang Gonad Ikan Kembung (Rastrelliger sp) di Perairan Desa Sidangoli Dehe Kecamatan Jailolo Selatan Kabupaten Halmahera Barat
}

\author{
Salim Abubakar ${ }^{1 *}$, Riyadi Subur ${ }^{1}$, Irmalita Tahir ${ }^{2}$ \\ ${ }^{1}$ Program Studi Manajemen Sumberdaya Perairan FPK-Unkhair \\ ${ }^{2}$ Program Studi KelautanFPK-Unkhair
}

\section{Article history}

Received: 23 Januari 2019

Revised: 28 Januari 2019

Accepted: 8 Februari 2019

Published: 13 Februari 2019

*Corresponding Author:

Salim Abubakar,

Program Studi Manajemen

Sumberdaya Perairan FPK-

Unkhair

Email:

salimbbkr@gmail.com

\begin{abstract}
Abstrak: Tujuan dari penelitian ini adalah untuk mengetahui ukuran pertama kali matang gonad dan ukuran mata jaring gillnet untuk penangkapan ikan kembung (Rastrelliger sp) di perairan Sidangoli Dehe. Pengambilan sampel dengan mengikuti kegiatan operasi penangkapan.dengan nelayan. Operasi penangkapan ikan dilakukan sebanyak 2 kali setiap minggu dan dilakukan selama satu bulan. Hasil tangkapan diambil secara acak (random sampling). Hasil tagkapan selanjutnya dilakukan pengukuran panjang cagak dan body girth. Penentuan tingkat kematangan gonad (TKG) yang dilakukan secara visual dengan melihat bentuk, warna serta perkembangan isi gonad.Hasil penelitian diperoleh ukuran pertama kali matang gonad ikan kembung (Rastrelliger $\mathrm{sp}$ ) yang tertangkap di perairan Desa Sidangoli Dehe dengan kisaran panjang cagak 250,7 mm sedamgkan ukuran mata jaring insang minimum yang sebaiknya digunakan untuk penangkapan ikan kembung (Rastrelliger $\mathrm{sp})$ yaitu $11,8 \mathrm{~cm}$ (4,6 inchi).
\end{abstract}

Kata Kunci : Matang gonad, mata jaring, Rastrelliger sp, Sidangoli Dehe

Abstract: The purpose of this study is to determine the size of first-time gonads and the size of gill-net for catching mackerel (Rastrelliger sp) in Dehe Sidangoli waters. Sampling by taking part in arrest operationswith fishermen. Fishing operations are carried out twice a week and carried out for one month. The catch is taken randomly. The result of the next tag is the measurement of the fork length and body girth. Determination of the level of gonad maturity (TKG) that is done visually by looking at the shape, color and development of gonadal contents. The results showed that the first size of mackerel gonad (Rastrelliger $\mathrm{sp}$ ) that was caught in the waters of Sidangoli Dehe Village with a fork length of $250.7 \mathrm{~mm}$ was the minimum size of the gill-net which should be used for catching mackerel (Rastrelliger $\mathrm{sp}$ ) which was $11.8 \mathrm{~cm}(4.6$ inches).

Keywords: Gonad mature, mesh, Rastrelliger sp, Sidangoli Dehe

\section{Pendahuluan}

Ikan kembung merupakan salah satu ikan pelagis kecil yang banyak ditangkap oleh nelayan dengan menggunakan alat tangkap pancing ulur, jaring insang, dan pukat cincin. Alat tangkap pukat cincin merupakan alat tangkap semi modern yang sampai saat ini hanya sedikit nelayan yang mengoperasikan dengan pertimbangan biaya operasional yang terlalu tinggi. Nelayan lebih memilih pancing ulur dan jaring insang yang merupakan alat tangkap tradisional dengan rancangan dan konstruksi yang lebih sederhana. Alat tangkap ini kebanyakan beroperasi di daerah pesisir dan dilakukan oleh nelayan tradisional setiap hari, sehingga ikan kembung bisa ditemukan 
di pasar dengan ukuran yang tidak bervariasi. Ukuran yang tidak bervariasi tersebut secara biologis menjadi salah satu fenomena dan indikator bahwa sumberdaya telah mengalami tekanan penangkapan di alam yang dapat mengancamkeberlanjutan sumber daya tersebut (Kasmi et al.,2017).

Ikan kembung merupakan salah satu ikan pelagis kecil yang sangat potensial dan di-temukan hampir di seluruh perairan Indonesia. Ikan kembung merupakan ikan yang memiliki nilai ekonomis penting. Ikan ini sangat mudah ditangkap dalam jumlah yang banyak karena memiliki sifat hidup yang bergerombol (schooling (Prahadina et al.,2015).

Ketersediaan ikan kembung (Rastrelliger canagurta), hampir dijumpai setiap hari. Sehingga anggapan kita bahwa jenis ikan ini seolah-olah selalu tersedia dan tidak ada habis-habisnya. Keadaan sebenarnya tidakalah demikian, eksploitasi yang terus menerus tanpa memperhatikan keberlanjutannya dapat menyebabkan penurunan kualitas dan kuantitas sumberdaya yang secara tidak langsung mampu menyebabkan kepunahan spesies. Keberlanjutan kesediaan ikan ditentukan oleh potensi pertumbuhan dan reproduksi ikan tersebut (Katiandagho dan Marasabessy, 2017).

Ikan kembung dikelompokan dalam dua jenis yaitu ikan kembung lelaki (Rastrelliger kanagurta) dan ikan kembung perempuan (Rastrelliger neglatus) Meskipun nama populernya menggunakan istilah lelaki dan perempuan namun tidak ada hubungan dengan jenis kelami, perbedaan lainnya dapat dilihat dari warna dan tinggi badan (Kordi, 2010).

Eksploitasi sumberdaya ikan kembung (Rastrelliger canagurta), menyebabkan terjadinya penurunan hasil tangkapan. Karena penangkapan ikan dilakukan secara terus menerus. serta penangkapan terhadap ikan-ikan dewasa, baik yang matang gonad maupun yang tidak. Sehingga makin lama makin berkurang. Induk-induk ikan yang tersedia untuk menghasilkan ikan-ikan muda guna mempertahankan dirinya (Suruwaky dan Gunaisah, 2013).

Ukuran ikan pada saat pertama kali matang gonad sangat pentingdiketahui dalam rangka penerapan perikanan yang bertanggungjawab, dan dapat mereduksikekhawatiran akan kekurangan populasi ikan dimasa mendatang. Sebagai salah satu rujukan ukuran pertama kali matang gonad, seharusnya mendapat perhatian lebih dari penentu kebijakan, sehingga kekhawatiran akan berkurangnya populasi ikan di masa mendatang menjadi berkurang. Informasi ukuran pertama kalimatang gonad juga dapat digunakan sebagai indikator ketersediaan stok yang reproduktif.Selain itu, informasi ini juga dapat diaplikasikan pada penentuan ukuran mata jaring yang akandigunakan dalam penangkapan ikan kembung. Lingkar badan ikan di belakang operkulum digunakan sebagai rujukan dalam penentuan ukuran mata jaring minimum (Omar et al.,2015). Lebih lanjut dikatakan Atmaja dan Haluan (2003) bahwa alat tangkap jaring insang dengan sistem penangkapan menjerat ikan, ukuran mata jaring sama dengan lingkar badan. Akan tetapi pada alat tangkap dimana jaring berfungsi sebagai dinding, ukuran mata jaring harus lebih kecil dari lingkar badan.

Menurut Najamuddin et al., (2004), pendugaan ukuran pertama kali matang gonad merupakan salah satu cara untuk mengetahui perkembangan populasi dalam suatu perairan,seperti bilamana ikan akan memijah, baru memijah atau selesai memijah. Berkurangnya populasi ikan di masa mendatang dapat terjadi karena ikan yang tertangkap adalah ikan yang akan memijah atau ikan yang belum pernah memijah, sehingga sebagai tindakan pencegahan diperlukan penggunaan alat tangkap yang selektif.

Ukuran kali pertama matang gonad pada ikan disebabkan oleh perubahan kondisi lingkungan, faktor abiotik, genetik populasi, perbedaan letak wilayah, kualitas perairan, dan besarnya tekanan penangkapan. Fekunditas dipengaruhi oleh ukuran panjang dan bobot ikan, diameter telur, fertilitas, frekuensi pemijahan, 
ukuran telur, kondisi lingkungan, dan kepadatan populasi. Keberlanjutan sumber daya ikan kembung lelaki di perairan pesisir Takalar dapat dijaga dengan menangkap pada ukuran minimal di atas ukuran kali pertama matang gonad, yakni di atas $21,18 \mathrm{~cm}$ untuk jenis kelamin betina dan di atas 21,31 cm untuk jenis kelamin jantan (Kasmi et al., 2017).

Seiring dengan meningkatnya kebutuhan manusia akan sumberdaya perikanan khususnya ikan kembung (Rastrelliger $\mathrm{sp}$ ), maka pengelolaan pemanfaatan harus diusahakan semaksimal mungkin secara berkesinambungan tanpa mengganggu kelestariannya. Untuk mendukung hal tersebut perlu adanya data dan informasi yang cukup mengenai aspek biologi reproduksi dari ikan kembung tersebut.

Ikan kembung (Rastrelliger $\mathrm{sp}$ ) termasuk dalam kelompok ikan pelagis kecil yang dieksploitasi secara terus-menerus oleh nelayan Desa Sidangoli Dehe dengan menggunakan alat tangkap jaring insang (Gillnet). Penangkapan dilakukan tanpa memperhatikan musim pemijahan dan ukuran ikan yang sudah matang gonad sehingga dapat menyebabkan sumberdaya ikan kembung tersebut lama kelamaan akan punah.Tujuan dari penelitian ini adalah untuk mengetahui :ukuran pertama kali matang gonad dan ukuran mata jaring gillnet untuk penangkapan ikan kembung (Rastrelliger sp) di perairan Sidangoli Dehe.

\section{Bahan dan Metode}

Penelitian ini dilaksanakan di perairan Desa Sidangoli Dehe Kecamatan Jailolo Selatan Kabupaten Halmahera Barat. Waktu pelaksanaan penelitian selama enam bulan yaitu Mei-Oktober 2018. Pengambilan sampel dengan mengikuti kegiatan operasi penangkapan.dengan nelayan. Operasi penangkapan ikan dilakukan sebanyak 2 kali setiap minggu dan dilakukan selama satu bulan. Hasil tangkapan diambil secara acak (random sampling), dengan total sampel sebanyak 300 ekor.

Panjang cagak (FL) diukur antara ujung bagian kepala terdepan dan pangkal sirip ekor dengan menggunakan penggaris ketelitian $1 \mathrm{~mm}$. Sedangkan untuk pengukuran body girth $(B G)$ dengan cara melilitkan tali plastik ke bagian maksimal lebar tubuh ikan, yaitu antara bagian bawah (ventral) sampai pada bagian punggung (dorsal) tubuh ikan di belakang operculum.

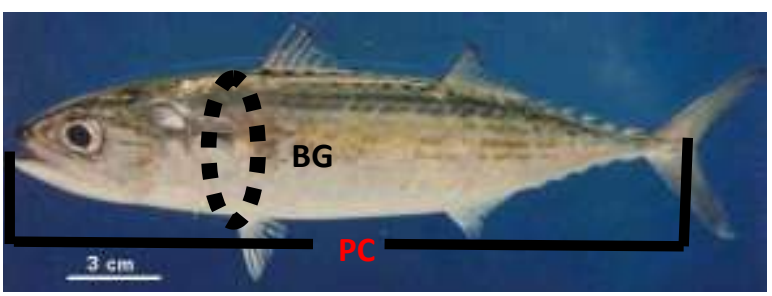

Gambar 1. Pengukuran Panjang Cagak (PC) dan Body Girth (BG) (Sumber : Kasmi et al., 2017)

Penentuan tingkat kematangan gonad (TKG) yang dilakukan secara visual dengan melihat bentuk, warna serta perkembangan isi gonad berdasarkan Effendie (2002). Klasifikasi tingkat kematangan gonad secara visual dapat dilihat pada Tabel 1 . 
Tabel 1. Klasifikasi Tingkat Kematangan Gonad Secara Visual

\begin{tabular}{|c|l|l|}
\hline Tingkat & Keadaan Gonad & \multicolumn{1}{|c|}{ Deskripsi } \\
\hline I & Belum matang & $\begin{array}{l}\text { Ovari berukuran kecil, bisa mencapai 1/2 dari panjang } \\
\text { rongga badan. Ovari berwarna kemerahan jernih. } \\
\text { Butiran telur belum tampak }\end{array}$ \\
\hline II & Perkembangan & $\begin{array}{l}\text { Ovari mengisi 1/2 dari panjang ronggabadan. Ovari } \\
\text { berwarna merah orange.Butiran telur belum tampak } \\
\text { jika diamati dengan mata telanjang. }\end{array}$ \\
\hline III & Pematangan & $\begin{array}{l}\text { Ovari mengisi 2/3 dari panjang rongga badan. Ovari } \\
\text { berwarna kuning orange, telah tampak butiran telur. } \\
\text { Pada permukaan ovari telah tampak pembuluh darah. } \\
\text { Telur masih berwarna gelap dan belum ada telur-telur } \\
\text { yang transparan }\end{array}$ \\
\hline IV. & Matang & $\begin{array}{l}\text { Ovari mengisi 2/3 sampai memenuhi rongga badan. } \\
\text { Ovari berwarna orange pink dengan pembuluh darah } \\
\text { tampak dipermukaannya. Telurtelur terlihat besar, } \\
\text { transparan dan matang }\end{array}$ \\
\hline V. & Mijah & $\begin{array}{l}\text { Ovari menyusut sampai 1/2 dari rongga badan. Dinding } \\
\text { tebal. Dalam ovari masih tersisa telur-telur berwarna } \\
\text { gelap dan matang yang mengalami disintegrasi akibat } \\
\text { penyerapan }\end{array}$ \\
\hline
\end{tabular}

Pendugaan ukuran pertama kali matang gonad dianalisis dengan metode Sperman Karber (Udupa, 1986 dalam Kasmi et al., 2017).

$$
\log M=X k+\frac{X}{2}-\left(X \sum p i\right)
$$

Keterangan :

$X_{k}=$ Logaritma nilai tengah terakhir pada saat ikan matang gonad (100\%).

$\mathrm{X}=$ Selisih logaritma nilai tengah kelas

$\mathrm{Xi}=$ Logaritma nilai tengah kelas

pi $=$ ri $/$ ni

ri = Jumlah ikan matang gonad pada kelas ke-i

ni = Jumlah ikan pada kelas ke-i

Hubungan antara body girth dengan panjang cagak dianalisis dengan menggunakan regresi liniear sederhana (Steel and Torrie, 1982 dalam Musbir et al., 2006) dengan persamaan sebagai berikut:

$$
Y=a+b X
$$

Keterangan:

$\mathrm{Y}=$ Panjang cagak $(\mathrm{mm})$

$\mathrm{X}=$ Lingkar badan $($ Body girth) (mm)

\section{Hasil dan Pembahasan}

\section{Tingkat Kematangan Gonad (TKG)}

Komposisi tingkat kematangan gonad ikan kembuang (Rasterlliger sp) yang tertangkap dengan jaring insang di perairan Sidangoli Dehe dapat di lihat pada Gambar 2.

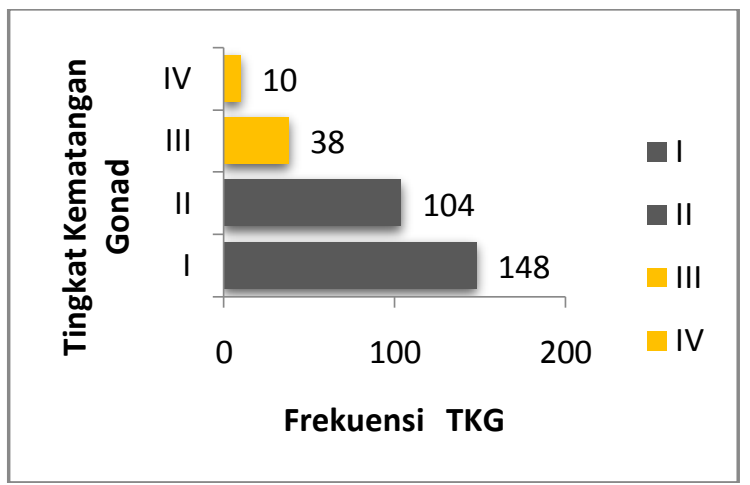

Gambar 2. Komposisi Tingkat Kematangan Gonad (TKG) Ikan Kembung

Gambar 2 tersebut menunjukkan bahwa TKG ikan kembung (Rastrelligersp) yang tertangkap di 
perairan Desa Sidangoli Dehe pada Bulan Oktober sebanyak 4 tingkatan yaitu TKG I, II, II dan IV. Dari 300 ekor ikan yang di bedah diperoleh komposisi TKG tertinggi terdapat pada TKG I sebanyak 148 ekor, selanjutnya TKG II sebanyak 104 ekor, TKG III sebanyak 38 ekor dan terendah pada TKG IV sebanyak 10 ekor. TKG I dan II memiliki komposisi lebih tinggi, hal ini menunjukkan bahwa ikan kembung (Rastrelliger sp) yang tertangkap di perairan Desa Sidangoli Dehe pada Bulan Oktober dalam proses masa pemijahan yang ditandai dengan belum matang. Sedangkan TKG III dan IV merupakan tahapan matang dimana gonad berwarna putih kekuningkuningan, butiran telur sudah dapat terlihat dengan mata telanjang dan TKG III dan IV dalam tahap siap pijah, dimana butiran telur membesar dan berwarna kuning jernih, dapat keluar dengan sedikit penekanan pada bagian perut.

Menurut Effendie (2002), perkembangan gonad yang semakin matang merupakan bagian dari reproduksi ikan sebelum terjadi pemijahan. Lebih lanjut dikatakan bahwa perkembangan gonad yang semakin matang merupakan bagian dari reproduksi ikan sebelum terjadi pemijahan.

Dalam biologi perikanan, pencatatan perubahan atau tahapan kematangan gonad diperlukan untuk mengetahui perbandingan ikanikan yang akan melakukan produksi dan yang tidak. Tahapan kematangan gonad ini juga didapatkatkan katerangan bila mana ikan akan memijah, baru memijah, atau selesai memijah. (Effendie, 2002). Hasil penelitian Basarun (2009) di Desa Prapakanda Kabupaten Halmahera Selatan pada Bulan Desember diperoleh ikan kembung dengan TKG II, III, IV dan V dengan persentase tertinggi pada TKG III sebanyak 51 ekor dari jumlah ikan yang dibedah. Hal ini menunjukkan bahwa ikan kembung dapat memijah setiap tahun dan masa puncak pemijahan pada bulan Oktober-Desember.

Perbedaan kematangan gonad ikan kembung disebabkan karena adanya perbedaan laju pertumbuhan dan kualitas perairan, selain itu adanya tekanan dari penangkapan karena masyarakat Sidangoli Dehe selalu melakukan penangkapan secara terus menerus terhadap ikan kembung. Menurut Laleyeet al. (2006) dalam Kamsi et al., (2017), perkembangan kematangan gonad ikan bisa berbeda disebabkan oleh sifat genetik populasi, perbedaan laju pertumbuhan dan kualitas perairan selain itu bisa disebabkan oleh perbedaan wilayah dan tekanan penangkapan.

Beberapa alternatif pengelolaan yang dapat dilakukan adalah mengatur waktu penangkapan yaitu tidak melakukan penangkapan berlebih pada waktu puncak pemijahan. Puncak pemijahan ikan kembung laki-Laki (Rastrelliger kanagurta) yaitu bulan April-Juni sehingga ikan-ikan yang matang gonad tidak banyak tertangkap agar proses pemijahan tidak terganggu (Katiandagho dan Marasabessy,2017). Lebih lanjut dikatakanNugroho dan Murdijah (2006), ikan kembung akan memijah pertama kali pada umur dua tahun yang dilakukan secara periodik dengan selang waktu pemijahan dua kali yaitu puncaknya pada bulan Maret dan Oktober.

\section{Pendugaan Ukuran Pertama Kali Matang Gonad}

Ikan kembung (Rastrelliger $\mathrm{sp}$ ) yang diukur sebanyak 300 ekor, diperoleh kisaran panjang cagak yaitu $151-290 \mathrm{~mm}$. Dari kisaran ukuran tersebut, diperoleh ikan yang matang gonad sebanyak 48 ekor dan belum matang sebanyak 252 ekor. Dari Gambar 2 tersebut kisaran ukuran dari 150-213 belum matang gonad sedangkan kisaran 214-293 sudah matang gonad. Kisaran ikan yang belum batang dan telah matang disajikan pada Gambar 3 sedangkan persentase kematangan gonad disajikann pada Gambar 4. 


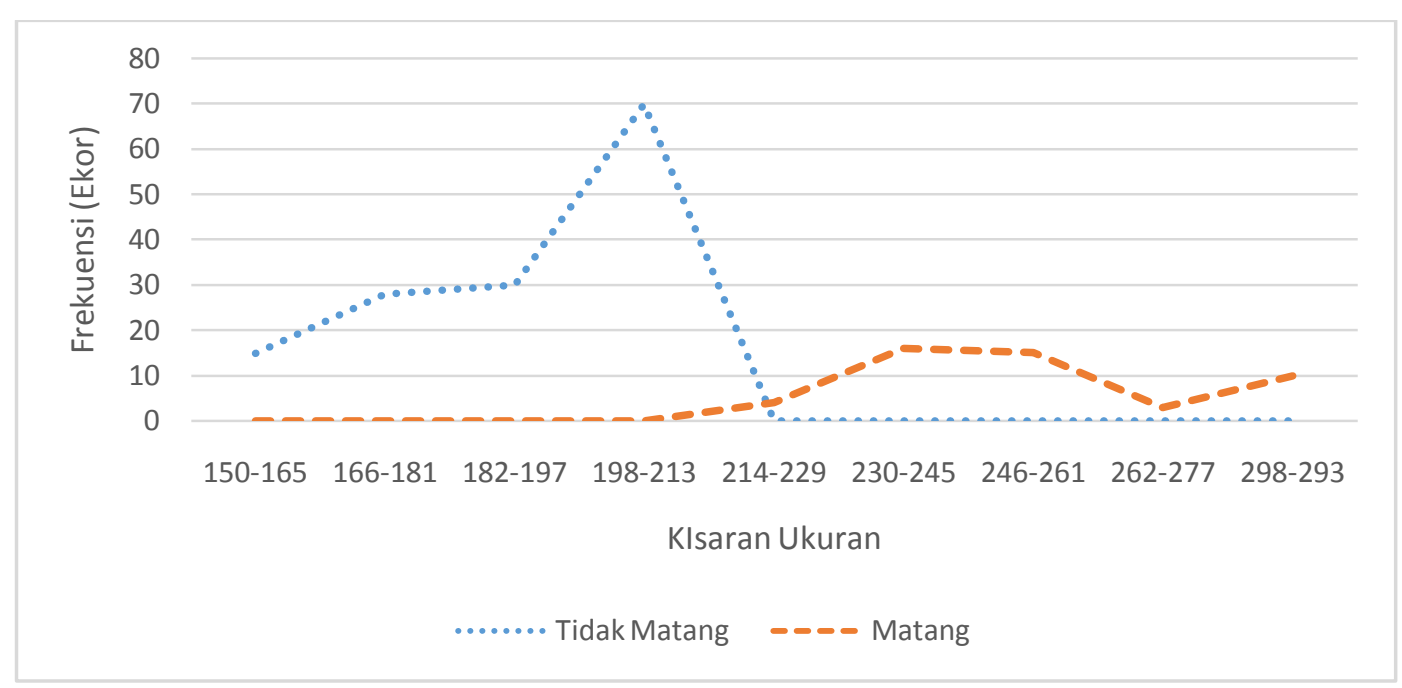

Gambar 4. Sebaran ukuran panjang ikan kembung berdasarkan perkembangan gonad periode April-September 2018.

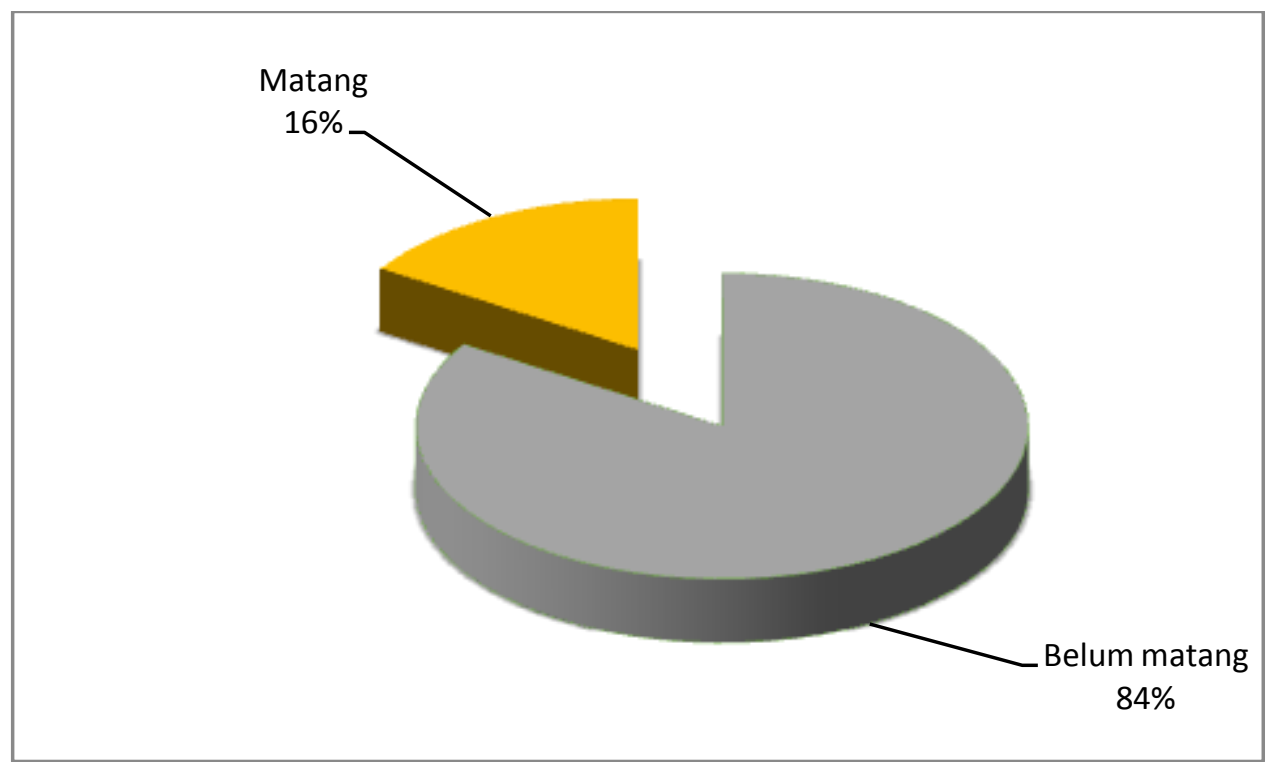

Gambar 5. Persentase Kematangan Gonad Ikan Kembung (Rastrelliger sp)

Gambar 5 tersebut, menunjukkan bahwa ikan kembung yang tertangkap pada bulan Oktober 2018 di perairan Sidangoli Dehe dengan menggunakan jaring insang diperoleh persentase gonad yang belum matang lebih tinggi sebesar $84 \%$ dan $16 \%$ gonad telah matang. Bila dibandingkan dengan hasil penelitian Musbir $d k k$. (2006) di perairan laut Flores Sulawesi Selatan pada bulan September
2006 - Pebruari 2007, diperoleh 50\% ikan kembung memiliki gonad yang telah matang.

Penentuan ukuran pertama kali matang gonad dari ikan kembung yang diperoleh dapat dilihat pada Tabel 1. 
Tabel 1. Distribusi frekuensi panjang cagak dan ukuran pertama kali matang gonad ikan kembung (Rastrelliger $\mathrm{sp}$ )

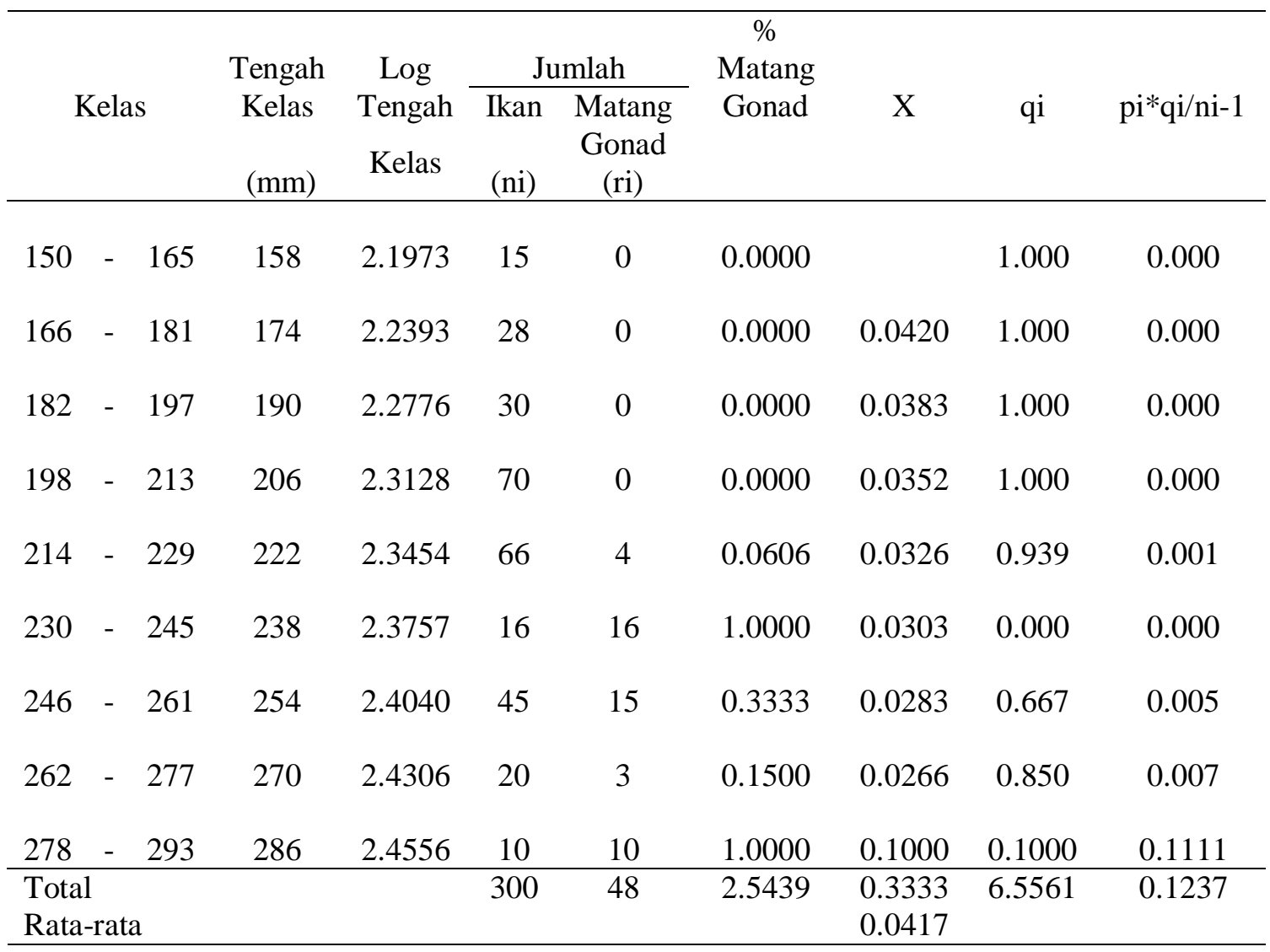

Hasil analisis ukuran ikan kembung yang tertangkap di Desa Sidangoli Dehe memiliki kisaran panjang cagak yang bervariasi yaitu antara 150 - $293 \mathrm{~mm}$. Kisaran panjang cagak yang memiliki frekuensi tertinggi yaitu 198-213 mm sebanyak 70 ekor, kemudian diikuti kisaran panjang cagak 214-229 mm dengan frekuensi 66 ekor, kisaran pajang cagak 246-261 mm (45 ekor), kisaran panjang cagak 182-197 mm (30 ekor), kisaran panjang cagak 166-181 mm (25 ekor), kisaran panjang cagak 262-277 mm (20 ekor), kisaran panjang cagak 230-245 mm (16 ekor), kisaran panjang cagak 150-165 mm (15 ekor), kisaran panjang cagak 278-293 mm (10 ekor) dan kisaran panjang cagak yang memiliki frekuensi terendah terdapat pada ukuran 262-277 mm dengan frekuensi 3 ekor. Persentase dari ikan-ikan yang matang gonad (TKG III dan IV) diplot terhadap kelas panjang dan ukuran ikan pada pertama kali matang gonad diperoleh $79 \%$ dari jumlah individu yang matang gonad berada pada TKG III dan $21 \%$ pada TKG IV.

Effendie (2002) menyatakan bahwa tiaptiap spesies ikan pada waktu pertama kali gonadnya menjadi masak tidak sama ukurannya, demikian pula ikan yang sama spesiesnya. Lebih-lebih bila ikan yang sama spesiesnya itu tersebar pada lintang yang perbedaannya lebih dari lima derajat, maka akan terdapat perbedaan ukuraan ketika mencapai kematangan godan pertamakalinya.

Dari hasil analisis ukuran pertama kali matang gonad pada Tabel 1 tersebut, diperoleh ikan kembung (Rastrelliger sp) yang tertangkap di perairan Desa Sidangoli Dehe pada rata-rata ukuran 
panjang cagak 234,7 mm dengan kisaran antara 219,7-250,7 mm. Hasil yang didapat dari penelitian ini berbeda dengan hasil penelitian yang telah dilakukan oleh beberapa penelitian seperti Musbir et al., (2006) di laut flores dengan ukuran panjang cagak 200,3 mm.Menurut Udupa (1974) dalam Musbir et al., (2006), bahwa panjang pada pertama kali matang adalah bervariasi antara jenis maupun dalam jenis itu sendiri, dengan demikian individu yang berasal dari satu kelas umur tidak selalu mencapai panjang pertama kali matang pada ukuran yang sama.

Kantun et al., (2015) berpendapat bahwa semakin banyak ikan yang tertangkap di atas ukuran kali pertama matang gonad, maka peluang untuk menjaga eksistensinyasemakin besar. Oleh sebab itu sangat penting dalam melakukan pengelolaan memperhatikan aspek biologi reproduksi ikan agar keberlanjutan sumber daya ikan kembung lelaki dapat terjamin.

\section{Penentuan Ukuran Mata Jaring}

Hasil analisis hubungan antara lingkar badan dengan panjang cagak ikan kembung didapatkan hubungan yang linier dengan korelasi 0,81 dan koefisien determinasi 0,66 . Hasil analisis keragaman menunjukkan bahwa model persamaan tersebut dapat diterima dan secara sah berbentuk linier regresi karena diperoleh Fhitung (572,8166 > F tabel baik 5\% $(3,89)$ maupun $1 \% \quad(6,79)$. Persamaan hubungan antara panjang cagak (X) dan lingkar badan (Y) didapatkan $\mathrm{Y}=1,0785+$ 0,9379X.Menurut Hariwijaya dan Triton (2007), untuk menentukan kekuatan hubungan antara dua variabel (fork length dengan girth) dapat diketahui berdasarkan nilai r. Lebih lanjut dikatakan Omar $d k k$.(2015) bahwa lingkar badan ikan di belakang operkulum digunakan sebagai rujukan dalam penentuan ukuran mata jaring minimum.

Noija et al., (2008) dalam Rahantandan Puspito (2012) yang menyebutkan bahwa jika ukuran keliling tubuh maksimum ikan hampir sama dengan keliling mata jaring, maka kemungkinan ikan-ikan tersebut akan tertangkap secara terjerat (gilled). Begitupun jika ikan memiliki keliling tubuh maksimum sedikit lebih besar dari keliling mata jaring, maka ikan akan tertangkap secara gilled juga. Selanjutnya jika keliling tubuh maksimum ikan jauh lebih besar dari keliling mata jaring, maka ikan tertangkap secara entangled.

Menurut Ayodhyoa (1981) dalam Making et al., (2014) bahwa antara mesh size dan besar ikan terdapat hubungan yang erat atau dengan perkataan lain gillnet akan bersifat selektif terhadap ukuran dari ikan yang diperoleh. Jadi dalam melakukan suatu penangkapan dengan mengunakan gillnet hal penting yang perlu diperhatikan adalah penggunaan mesh size yang tepat sehingga ikan-ikan kecil diberi kesempatan untuk lolos sehingga tidak terjadi overfishing dikemudian hari.

Dari perhitungan ukuran pertama kali matang gonad diperoleh kisaran panjang cagak antara 219,7-250,7 mm. Sebagai faktor kehatihatian dan keamanan populasi, maka dalam penentuan ukuran mata jaring merujuk pada batas maksimum (Najamudin et al.,2004). Berdasarkan pernyataan ini, maka batas maksimum dari panjang cagak ikan kembung yang diperoleh yaitu 250,7 $\mathrm{mm}$, nilaiini kemudian dimasukkan kedalam persamaan regresi yang diperoleh maka didapatkan lingkar badan sebesar 342,98 mm. Sehingga didapatkan ukuran mata jaring minimum untuk Gill net adalah seperdua dari lingkar badan atau sama dengan $118,1 \mathrm{~mm}$ atau $11,8 \mathrm{~cm}$ (4.6 inchi). Alat tangkap gill net yang digunakan untuk menangkap ikan kembung di Desa Sidangoli Dehe memiliki ukuran mata jaring 2,5 inchi $(6,25 \mathrm{~cm})$. Keadaan ini menjadikan ikan-ikan yang belum matang gonad dapat tertangkap lebih banyak. Hal ini berarti bahwa secara biologis bisa mengganggu kelestarian sumberdaya perikanan kembung. Jadi untuk mencegah kemungkinan gangguan terhadap kelestarian sumbedaya ikan kembung secara ideal, ikan-ikan yang ditangkap sudah pernah melakukan pemijahan. Menurut Rahantan dan Puspito (2012), kisaran ukuran ikan yang tertangkap oleh suatu ukuran mata jaring tertentu dapat diprediksi 
berdasarkan pada hubungan antara panjang garpu (fork length) dan keliling badan ikan.

$$
\text { Dalam rangka mempertahankan }
$$

keberlanjutan populasi ikan kembung (Rastrelliger sp) di perairan Desa Sidangoli Dehe perlu penerapan peraturan penggunaan ukuran mata jaring minimum. Dengan membiarkan ikan-ikan memijah minimal sekali akan mencegah degradasi stok jika target penangkapan teralampaui.

\section{Kesimpulan}

Ukuran pertama kali matang gonad ikan kembung (Rastrelliger sp) yang tertangkap di perairan Desa Sidangoli Dehe dengan kisaran panjang cagak 250,7 mmdan ukuran mata jaring minimum yang sebaiknya digunakan untuk menangkap ikan kembung (Rastrelliger sp) yaitu $11,8 \mathrm{~cm}(4,6$ inchi).

\section{Ucapan Terima kasih}

Terimakasih yang sebesar-besarnya kami sampaikan kepada LPPM-Unkhair, atas dukungan dana, sehingga penelitian ini dapat dilaksanakan. Kepada semua pihak yang turut mendukung penelitian ini, kamu ucapkan terimakasih yang tak terhingga.

\section{Daftar Pustaka}

Atmaja, S. B \& Haluan, J. (2003). Perubahan Hasil Tangkapan Lestari Ikan Pelagis Kecil di Laut Jawa dan Sekitarnya. Buletin Pemanfaatan Sumberdaya Perikanan Volume XII. No.2/10/20.

Efendie, M. I. (2002). Biologi Perikanan. Yayasan Pustaka Nusatama. Yogyakarta.

Hariwijaya, M \& Trinton, P.B. 2007. Pedoman Penulisan Ilmiah Propsoal dan Skripsi. Oriza. Yogyakarta.
Kantun, W., Syamsu, A., Achmar, M. \& Ambo, T. (2015). Potensi reproduksi tuna madidihang Thunnus albacares di Selat Makassar. In: Zainuddin IM (Editor). Prosiding SimposiumNasional Pengelolaan Perikanan Tuna Berkelanjutan. Bali 10-11 Desember 2014 II-142. World Wildlife Foundation-Indonesia. $1259 \mathrm{p}$.

Kasmi, M., S. Hadi \& W. Kantun. (2017). Biologi reproduksi ikan kembung lelaki, Rastreliger kanagurta (Cuvier, 1816) di Perairan Pesisir Takalar, Sulawesi Selatan. Jurnal Iktiologi Indonesia, 17(3): 259-271.

Katiandagho, B. \& F. Marasabessy (2017). Potensi Reproduksi, Pola Pemijahan Serta Alternatif Pengelolaan Ikan Kembung Laki-Laki (Rastrelliger kanagurta) Di Sekitar PesisirTimur Perairan Biak. Jurnal Ilmiah agribisnis dan Perikanan (agrikan UMMU-Ternate) Volume 10 Nomor 2 Oktober 2017.

Making, A.D.L, Asriyanto \& Taufik, Y. (2014). Pengaruh Perbedaan Mata Jaring (Mesh size) Gillnet Terhadap Cara Tertangkap Ikan Kembung Perempuan (Scomber neglectus) Di Perairan Morodemak Kabupaten Demak. Journal of Fisheries Resources Utilization Management and Technology. Volume 3, No. 4 Tahun 2014. h. 120-129.

Musbir, Mallawa, A., Sudirman \& Najamudin. (2006). Pendugaan Ukuran Pertama Kali Matang Gonad Ikan Kembung, Rastrelliger kanagurta Di Perairan Laut Flores Sulawesi Selatan. Program Pasca Sarjana Jurusan Sains dan Teknologi, Fakultas Ilmu Kelautan dan Perikanan, Universitas Hasanuddin. Makassar.April 2006, Vol. 6 No. 1: 19 - 26 ISSN 1411-4674 
Najamuddin, Mallawa, A., Budimawan \& Indar, M. Y. N. (2004). Pendugaan Ukuran Pertama Kali Matang Gonad Ikan Layang Deles (Decapterus macrosoma Bleeker). Program Pasca Sarjana Jurusan Sains dan Teknologi, Fakultas Ilmu Kelautan dan Perikanan, Universitas Hasanuddin. Makassar.April 2004, Vol. 4 No. 1:1-8. ISSN 1411-4674

Nugroho, A. \& Murdijah (2006). Hubungan Panjang Berat, Perbandingan Jenis Kelamin dan Tingkat Kematangan Gonad Ikan Ikan Kembung Di Laut Banda. Jurnal Penelitian Perikanan Indonesia. 12:195200.

Suruwaky, A.M \& Gunaisah, E. (2013). Identifikasi Eksploitasi Tingkat Sumberdaya IKan Kembung Lelaki (Rastrelliger kanagurta) Di Tinjau Dari Hubungan Panjang Berat. JUrnal AKuatika ISSN 0853-2523 Vol. IV No. 2/September 2013 (131-140).

Omar, S. B. A, M. N. Moh, T. Umar, Muh. A. Dahlan \& Syarifuddin K. (2015). Nisbah Kelamin Dan Ukuran Pertama Kali Matang Gonad Ikan Endemik Pirik (Lagusia micracanthus bleeker, 1860) Di Sungai Pattunuang, Kabupaten Maros dan Sungai Sanrego, Kabupaten Bone Sulawesi selatan. Seminar Nasional Tahunan XII Hasil Penelitian Perikanan dan Kelautan, 08 Agustus 2015. Semnaskan_Universitas Gajahmada.

Prahadina, V.D, M. Boer \& A. Fahrudin (2015). Sumberdaya ikan kembung (Rastrelliger kanagurta cuvier 1817) di Perairan Selat Sunda Yang Didaratkan Di Ppp Labuan, Banten. Jurnal Marine FisheriesISSN $2087-$ 4235 Vol. 6, No. 2, November 2015.

Rahantan, A. \& Puspita, G. (2012). Ukuran Mata dan Shortening Yang Sesuai Untuk Jaring
Insang Yang Dioperasikan Di Perairan Tual. Jurnal Mrine Fisheries Vol. 3, No. 2 November 2012. 